\title{
Phosphorus and thermotolerant coliforms' loads in Brazilian watersheds with limited data: considerations on the integrated analysis of water quality and quantity
}

\section{Cargas de fósforo e coliformes termotolerantes em bacias brasileiras com dados escassos: considerações sobre análises integradas de qualidade e quantidade de água}

\author{
Luis Otávio do Amaral Marques ${ }^{1}$, Denise Taffarello ${ }^{1}$, Maria do Carmo Calijuri ${ }^{1}$, Eduardo Mario Mendiondo ${ }^{1}$, \\ Murilo de Souza Ferreira ${ }^{1}$ and Davi Gasparini Fernandes Cunha ${ }^{1}$ \\ ${ }^{1}$ Escola de Engenharia de São Carlos, Universidade de São Paulo, São Carlos, SP, Brasil \\ E-mails: luis.otavio.marques@usp.br (LOAM),dt@sc.usp.br (DT), calijuri@sc.usp.br (MCC), emm@sc.usp.br (EMM), \\ muriloferreira@usp.br (MSF), davig@sc.usp.br (DGFC)
}

Received: September 02, 2017 - Revised: September 17, 2018 - Accepted: October 10, 2018

\begin{abstract}
Integrated analyses of the qualitative and quantitative aspects of aquatic ecosystems play an important role in decision making, which is linked to water resources management and promotion of ecosystem services. However, the possible advantages of such integration are still hampered by basic aspects, such as high uncertainties due to the partial and non-synchronized monitoring of discharges and observed concentrations of water quality variables. The lack of data has been limiting the adequate representation of a more accurate hydrological regime, which is in turn possibly affected by the potential effects of land use and size of drainage areas. The aim of this research was to discuss the advantages of the integrated analysis of qualitative and quantitative data from water bodies. Under different specific discharge regimes $\left(\mathrm{L}_{\mathrm{s}} \mathrm{s}^{-1} \cdot \mathrm{km}^{-2}\right)$, we assessed the total phosphorus (TP, t.day $\left.{ }^{-1} \cdot \mathrm{km}^{-2}\right)$ and thermotolerant coliforms' (TC, CFU.day $\left.{ }^{-1} \cdot \mathrm{km}^{-2}\right)$ specific loads in rivers with different drainage areas $\left(27-26,500 \mathrm{~km}^{2}\right)$ and land uses. We compared such loads with the admissible specific loads for these variables, which were estimated based on long-term average discharges and water quality guidelines (i.e., Brazilian environmental standards). Based on data from 2001-2013, we sought to contribute to the qualitative and quantitative analysis of surface waters, focusing on the discussion of the results on critical thresholds of duration and critical loads and discharges. The results showed the existence of significant time intervals with conflicts between the specific admissible and observed loads. This non-compliance varied between 10 and $100 \%$ of the duration of the regime for TP, and between 25 and $100 \%$ for TC, with a more critical situation observed in rivers with smaller drainage areas. The critical loads ranged from $110^{-4}$ to $810^{-3} \mathrm{t}^{\mathrm{d} d a y^{-1}} \cdot \mathrm{km}^{-2}(\mathrm{TP})$ and $110^{-2}$ to $11^{-1} \mathrm{CFU} \cdot \mathrm{day}^{-1} \cdot \mathrm{km}^{-2}$ (TC). Although a relatively limited dataset was considered (total $\mathrm{N}=1,402$ ), the significant variations in discharges and critical loads highlighted the need for considering how these dynamics would affect the traditional methodology for estimating ecological flows, whose current approach is almost exclusively quantitative.
\end{abstract}

Keywords: Poor gauged basins; Frequency curves; Water quality and quantity integration; Nutrients; Faecal contamination indicators.

\section{RESUMO}

Análises integradas dos aspectos qualitativos e quantitativos de ambientes aquáticos robustecem a tomada de decisão, que se vincula ao gerenciamento dos recursos hídricos e à promoção dos serviços ecossistêmicos. Contudo, as possíveis vantagens desta integração ainda esbarram em aspectos básicos, como elevadas incertezas devido ao monitoramento parcial e não sincronizado entre vazões e concentrações. A escassez de dados tem limitado a fiel representação mais acurada de um regime hidrológico, este sujeito aos potenciais efeitos de uso de solo e do tamanho das bacias de drenagem. O objetivo da presente pesquisa foi apresentar uma discussão inicial sobre as vantagens da análise integrada de dados quali-quantitativos dos recursos hídricos. Para isso, em diferentes regimes de vazões

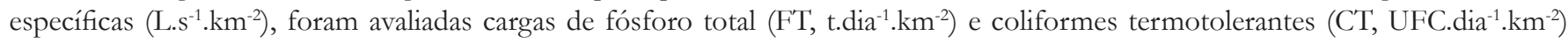
em rios com diferentes áreas de drenagem $\left(27-26.500 \mathrm{~km}^{2}\right)$ e usos do solo. Tais cargas foram comparadas com as cargas específicas admissíveis para essas variáveis, estimadas com base em vazões médias de longo período e padrões de qualidade. Dessa forma, a partir 
Phosphorus and thermotolerant coliforms' load in Brazilian watersheds with limited data: considerations on the integrated analysis of water quality and quantity

da compilação de dados de 2001-2013, buscou-se contribuir para a análise quali-quantitativa das águas superficiais, focando a discussão dos resultados em limiares críticos de duração e cargas e vazões críticas. Os resultados evidenciaram a existência de significativos intervalos de tempo com conflitos entre as cargas específicas admissíveis e observadas. Essa incompatibilidade variou entre 10 e 100\% da duração do regime para o FT, e entre 25 e 100\% para os CT, com situação mais crítica observada nos rios com menores

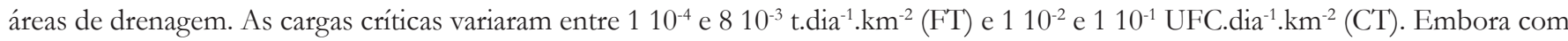
um número de dados relativamente limitado (Ntotal=1.402), as expressivas variações das vazões e das cargas críticas evidenciam a necessidade de uma reflexão sobre como essa dinâmica afetaria a metodologia tradicional para estimativa de vazões ecológicas, hoje baseada em abordagem, quase exclusivamente, quantitativa.

Palavras-chave: Bacias com dados escassos; Curvas de permanência; Integração quali-quantitativa; Nutrientes; Indicadores de contaminação fecal.

\section{INTRODUCTION}

Watersheds play a crucial role in a variety of ecosystem services (ES) and support human well-being (GROOT; WILSON; BOUMANS, 2002; FISHER; TURNER; MORLING, 2009; VÖRÖSMARTY et al., 2010). ES concerning protection and regulation provided by these catchments include hydrological services, which are affected by various interferences and impacts such as: (i) changes in land use and natural shifts of hydrological regimes (COSTANZA et al., 2014; BU et al., 2014; FREIRE; CASTRO, 2014); (ii) siltation and inputs of domestic and industrial wastewater (GONZALO; CAMARGO, 2013); and (iii) unplanned water withdrawals, with non-compliance with minimum environmental flows (GUPTA, 2008; ARTHINGTON et al., 2006).

The spatial and temporal dynamics of rivers and their drainage catchments, which is influenced by natural and anthropogenic factors, give rise to uncertainties in hydrological services. This might hinder water resources management and planning, such as when constructing scenarios for water regimes and integrating surface water quality and quantity aspects (SADEGH et al., 2016; FERREIRA; FERNANDES; KAVISKI, 2016; CALMON et al., 2016; BROWN et al., 2013; CUNHA; CALIJURI; MENDIONDO, 2012). Within this context, Pinto, Ribeiro and Silva (2016, p. 103) highlighted:

Although the Brazilian legislation reinforces the importance of adapting water resources management strategies considering biodiversity and promoting integration with environmental management, such legislation is still based on a conceptual basis of remaining flows associated with ecological and environmental approaches (our adapted translation, original document in Portuguese).

This also suggests that purely quantitative characterization of water availability as a function of mean/median values or relative percentiles of duration (e.g., $95 \%, \mathrm{Q}_{95}$ ) is probably insufficient if not associated with aspects related to water quality and land uses in watersheds.

Hydrological services are also related to the "river absorption capacity” (WILK; ORLIŃSKA-WOŹNIAK; GĘBALA, 2018), which is the maximum pollutant load that a water body can assimilate or tolerate with no resulting changes that affect its self-depuration capacity or compliance with standards and guidelines (BRASIL, 2005). The evaluation of such capacity has been used as an alternative to the "total maximum daily load" (TMDL), which is widely reported in the international literature (e.g., USACE, 2006; HSU et al., 2010; CHUNG et al., 2011;
CHEN et al., 2016; ABU-HMEIDAN; WILLIAMS; MILLER, 2018). Load duration and frequency curves can be useful to further integrate qualitative and quantitative datasets of water resources. Such curves can be designed, for example, by plotting discharge and load (concentration $\mathrm{x}$ discharge) values versus the probability that these magnitudes are either matched or exceeded during a given period of time (COLLISCHONN; DORNELLES, 2013; CRUZ; SILVEIRA, 2007; CRUZ; TUCCI, 2008; GENZ; LUZ, 2012).

One of the advantages of the quali-quantitative frequency curves is the possibility of estimating the percentage of time during which a hydrological regime condition (with associated discharge and concentration data) is compatible or not with water quality standards. Although based on probabilistic criteria of the hydrological regime and affected by sampling uncertainties, the integration of qualitative and quantitative data on surface water monitoring has different advantages. This approach provides estimates of critical values of loads and durations of the temporal regime of rivers. In addition, it preliminarily incorporates the diagnosis of ES in watersheds by integrating: 1) concentrations and river discharges as pollutant loads; 2) drainage areas; and 3) predominant land uses.

However, given the wide range of potential descriptors of river water quality, it is necessary to prioritize the parameters, depending on the purpose of the analysis. Different variables may present different situations in relation to the legal framework of the water bodies and the seasonal variation throughout dry and rainy seasons. Typically, the main impacts on environmental services are associated with anthropogenic activities. Thus, among the water quality variables, total phosphorus and thermotolerant coliforms are of special interest because they reflect human impacts on rivers and aquatic systems in general.

Phosphorus is a macronutrient for biological processes. It is associated with artificial eutrophication and can be a suitable indicator for both non-point (FISCHER et al., 2018; SCANLON; KIELY; XIE, 2004) and point source pollution. Domestic wastewater is one of the most important phosphorus sources for water bodies (mainly from detergents and faecal organic matter), as well as industrial effluents, such as those from slaughterhouses and dairy products (CETESB, 2009). Some recent literature reviews have shown that total phosphorus has been used as a parameter to evaluate the effectiveness of best management practices for water quality recovery (e.g., LIU et al., 2017; QI et al., 2017).

The integration of water qualitative and quantitative data has been used to evaluate ecosystem-based adaptation (EbA) projects (CBD, 2010). As one of the possible EbA methods 
(TAFFARELLO et al., 2017), some Brazilian projects on payment for ecosystem services consider total phosphorus loads in the calculation of the value to be paid, such as Oásis (SOVACOOL, 2011; NUNES et al., 2013; YOUNG; BAKKER, 2014). Other initiatives have quantified total phosphorus loads through environmental monitoring activities, such as in the Projeto Produtor de Águas/PCJ (Water Producer Project) (VIANI; BRACALE, 2015) in order to aid in the parameterization of hydrological models (TAFFARELLO et al., 2018).

Although thermotolerant coliforms are less effective indicators compared to Escherichia coli (PARUCH; MÆHLUM, 2012) and to some pathogenic viruses, they have been used to assess water quality and possible faecal contamination from anthropogenic sources. The lower effectiveness of thermotolerant coliforms as water quality indicators is associated to their lower resistance to several environmental conditions and significant variability in relation to different drainage areas (TAFFARELLO et al., 2016). However, thermotolerant coliforms are still used as indicators of faecal contamination in Brazilian water bodies.

In addition to the high variability of total phosphorus and thermotolerant coliforms in natural watersheds, the uncertainties regarding loads of such variables dramatically increase in rivers with limited data availability (FISCHER et al., 2018; LIU et al., 2017; QI et al., 2017; ZAFFANI et al., 2015; MENDIONDO, 2008). These uncertainties are relatively common in the traditional monitoring programs because the determination of water quality variables is usually not paired with the discharge estimations. For example, the Annual Water Quality Bulletin (IGAM, 2013) reported physical, chemical and bacteriological water variables in the state of Minas Gerais. For this report, the authors used Escherichia coli as an indicator of faecal contamination and total phosphorus as an indicator of organic matter enrichment. Although the results were compared with guidelines established by COPAM/CERH n ${ }^{\circ} 01 / 2008$, they were not integrated with discharge estimates. Even when discharge measurements are available, these data are rarely analyzed in association with water quality datasets. This affects the estimates of loads transported along the water bodies of the watersheds (ZUCCO et al., 2012; SCANLON; KIELY; XIE, 2004).

The main contribution of this paper is to discuss initial considerations about the integration of qualitative and quantitative data of surface freshwaters in watersheds with limited available information. Firstly, we compiled data on total phosphorus and thermotolerant coliforms to calculate pollutant loads in watersheds with different land use characteristics and contrasting drainage areas upstream the sampling sites. Moreover, we compared the observed specific loads of these variables with the loads that would comply with the legal framework of the study water bodies. The latter was based on the upper concentration limits defined by environmental standards (BRASIL, 2005). Thus, we considered different calculation tools and methods, such as frequency curves, specific discharge and pollutant loads, associating critical durations and critical values in the studied watersheds under a probabilistic approach.

\section{MATERIAL AND METHODS}

We compiled 952 direct estimations of river discharge, 270 data points on thermotolerant coliforms and 180 on total phosphorus. River drainage areas varied between 26 and $27,600 \mathrm{~km}^{2}$. The following sub-basins were selected for this study with available datasets from 2000-2013: Das Velhas, Doce, Pomba and Paraopeba (Minas Gerais State, MG, Southeast Brazil), and Iguaçu, Piraquara, Arroio Toledo and Passaúna (Paraná State, PR, South Brazil) (Table 1). The criteria for choosing these watersheds were related to contrasting drainage areas and availability of paired data within the online system Hydroweb from the National Water Agency (ANA) in Brazil.

Table 1. General characterization of the watersheds and drainage areas (in descending order), including predominant land uses

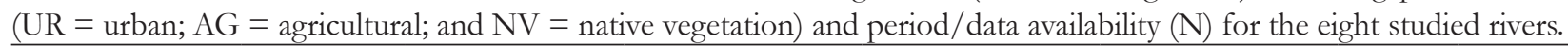

\begin{tabular}{|c|c|c|c|c|c|c|c|c|}
\hline \multirow[b]{2}{*}{$\begin{array}{l}\text { Sub-basin and } \\
\text { Brazilian state }\end{array}$} & \multirow[b]{2}{*}{$\begin{array}{l}\text { Drainage } \\
\text { area }\left(\mathrm{km}^{2}\right)\end{array}$} & \multirow[b]{2}{*}{$\begin{array}{l}\text { Geographic } \\
\text { coordinates }\end{array}$} & \multicolumn{3}{|c|}{ Qualitative and quantitative data } & \multicolumn{3}{|c|}{ Land use $(\%)$} \\
\hline & & & $\begin{array}{l}\text { Discharge } \\
\text { (1) }\end{array}$ & $\begin{array}{c}\text { Total } \\
\text { phosphorus (2) }\end{array}$ & $\begin{array}{c}\text { Thermotolerant } \\
\text { coliforms (2) }\end{array}$ & UR & AG & NV \\
\hline Das Velhas (MG) & 26,500 & $\begin{array}{l}17^{\circ} 35^{\prime} 41^{\prime \prime} \mathrm{S} \\
44^{\circ} 42^{\prime} 50^{\prime \prime} \mathrm{O}\end{array}$ & $\begin{array}{c}2000-2013 \\
(N=157)\end{array}$ & $\begin{array}{c}2001-2007 \\
(\mathrm{~N}=20)\end{array}$ & $\begin{array}{c}2000-2009 \\
(N=48)\end{array}$ & 10 & 80 & 10 \\
\hline Doce (MG) & 15,900 & $\begin{array}{l}19^{\circ} 46^{\prime} 37^{\prime \prime} \mathrm{S} \\
42^{\circ} 28^{\prime} 35^{\prime \prime} \mathrm{O}\end{array}$ & $\begin{array}{c}2000-2013 \\
(N=161)\end{array}$ & $\begin{array}{c}2001-2008 \\
(N=30)\end{array}$ & $\begin{array}{c}2001-2010 \\
(N=40)\end{array}$ & 1 & 15 & 84 \\
\hline Pomba (MG) & 5,880 & $\begin{array}{l}21^{\circ} 23^{\prime} 22^{\prime \prime} \mathrm{S} \\
42^{\circ} 42^{\prime} 07^{\prime \prime} \mathrm{O}\end{array}$ & $\begin{array}{l}2000-2013 \\
(N=118)\end{array}$ & $\begin{array}{c}2001-2010 \\
(\mathrm{~N}=24)\end{array}$ & $\begin{array}{c}2000-2010 \\
(28)\end{array}$ & 78 & 17 & 5 \\
\hline Paraopeba (MG) & 2,770 & $\begin{array}{l}20^{\circ} 24^{\prime} 29^{\prime \prime} \mathrm{S} \\
44^{\circ} 01^{\prime} 16^{\prime \prime} \mathrm{O}\end{array}$ & $\begin{array}{l}2000-2013 \\
(N=143)\end{array}$ & $\begin{array}{c}2000-2004 \\
(N=20)\end{array}$ & $\begin{array}{c}2000-2010 \\
(N=42)\end{array}$ & 38 & 51 & 11 \\
\hline Iguaçu (PR) & 814 & $\begin{array}{l}25^{\circ} 31^{\prime} 41^{\prime \prime} \mathrm{S} \\
49^{\circ} 133^{\prime}, 0\end{array}$ & $\begin{array}{l}2001-2010 \\
(N=120)\end{array}$ & $\begin{array}{l}2001,2004-2009 \\
\quad(\mathrm{~N}=23)\end{array}$ & $\begin{array}{c}2001-2010 \\
(\mathrm{~N}=44)\end{array}$ & 92 & 6 & 2 \\
\hline Piraquara (PR) & 102 & $\begin{array}{l}25^{\circ} 27^{\prime} 022^{\prime \prime} \mathrm{S} \\
49^{\circ} 07^{\prime} 166^{\prime \prime} \mathrm{O}\end{array}$ & $\begin{array}{c}2000-2010 \\
(\mathrm{~N}=71)\end{array}$ & $\begin{array}{c}2000,2003-2008 \\
(\mathrm{~N}=21)\end{array}$ & $\begin{array}{c}2000-2010 \\
(\mathrm{~N}=23)\end{array}$ & 62 & 30 & 8 \\
\hline $\begin{array}{l}\text { Arroio Toledo } \\
\text { (PR) }\end{array}$ & 61 & $\begin{array}{l}24^{\circ} 44^{\prime} 17^{\prime \prime} \mathrm{S} \\
53^{\circ} 41^{\prime} 21^{\prime \prime} \mathrm{O}\end{array}$ & $\begin{array}{c}2004-2008 \\
(\mathrm{~N}=52)\end{array}$ & $\begin{array}{c}2004-2006 \\
(\mathrm{~N}=14)\end{array}$ & $\begin{array}{c}2004-2006 \\
(N=8)\end{array}$ & 5 & 89 & 6 \\
\hline Passaúna (PR) & 27 & $\begin{array}{l}25^{\circ} 21^{\prime} 55^{\prime \prime} \mathrm{S} \\
49^{\circ} 21^{\prime} 17^{\prime \prime} \mathrm{O}\end{array}$ & $\begin{array}{c}2000-2010 \\
(N=130)\end{array}$ & $\begin{array}{c}2000-2008 \\
(\mathrm{~N}=28)\end{array}$ & $\begin{array}{c}2001-2010 \\
(\mathrm{~N}=37)\end{array}$ & 27 & 3 & 70 \\
\hline
\end{tabular}

MG = Minas Gerais State; PR = Paraná State; (1) Monthly means; (2) Data available from monitoring campaigns in February, April, August and October. Land use was estimated by supervised classification with satellite images from Google Earth (2018). 
Phosphorus and thermotolerant coliforms' load in Brazilian watersheds with limited data: considerations on the integrated analysis of water quality and quantity

To build the frequency curves, discharge is usually plotted on the ordinate against the percentage of time in abscissa (COLLISCHONN; DORNELLES, 2013). Therefore, each discharge value is equal or higher than a certain value with an associated probability of occurrence, considering a year as the reference time. Such curves can also be based on discharge values associated to concentrations of water quality variables to obtain load frequency curves. Similarly to discharge only approaches, different loads of a given pollutant can be associated with probabilities of occurrence (e.g., CUNHA; CALIJURI; MENDIONDO, 2012). In our study, the frequency curves were expressed as specific discharges $\left(\mathrm{L}_{\mathrm{s}} \mathrm{s}^{-1} \cdot \mathrm{km}^{-2}\right)$ and specific loads $\left(\mathrm{t} . \mathrm{day}^{-1} \cdot \mathrm{km}^{-2}\right.$ or CFU.day ${ }^{-1} \cdot \mathrm{km}^{-2}$ ) to normalize the data in terms of area and make the results more comparable in watersheds with different drainage areas. This normalization by the drainage area can be useful to highlight possible regionalization effects and different processes in watersheds with contrasting sizes and biomes.

The specific discharge frequency curves were built with the monthly average discharge available for the entire period analyzed in each river (Table 1). The qualitative-quantitative curves in turn were based on specific loads: (i) observed and (ii) in compliance with the Brazilian legal framework. In case (i), the curves were constructed using the monthly average discharges paired with data on either thermotolerant coliforms or total phosphorus (collected in February, April, August and October, Table 1). Thus, the data were not concentrated in a single seasonal period, but balanced and equally distributed in dry, rainy and intermediary periods throughout the years. In the second case (ii), the curves were constructed based on the monthly average discharges multiplied by environmental standards or references (i.e., upper limits) for total phosphorus $\left(0.1 \mathrm{mg} . \mathrm{L}^{-1}\right)$ and thermotolerant coliforms $\left(1.010^{3} \mathrm{CFU} / 100 \mathrm{~mL}\right)$ for Class 2 water bodies according to CONAMA 357 (BRASIL, 2005). Thus, the curves with loads in compliance with the Brazilian legal framework had twelve data points each, corresponding to monthly average river flows from January to December multiplied by a single fixed reference value (i.e., the environmental standard).

\section{RESULTS AND DISCUSSION}

\section{General characterization of the dataset}

During the compilation of data from the rivers in the online Hydroweb system, we observed that paired information on water quality and quantity is limited. Mean total phosphorus concentrations in the eight water bodies were frequently above baselines (e.g., reference concentrations) for this nutrient (e.g., 0.030.04 mg. $\mathrm{L}^{-1}$ as baselines for rivers in the São Paulo State, CUNHA; DODDS; CALIJURI, 2011, and $0.006 \mathrm{mg} . \mathrm{L}^{-1}$ as baselines for streams in Distrito Federal, FONSECA et al., 2014). According to Lamparelli (2004), total phosphorus concentrations higher than $0.137 \mathrm{mg} \cdot \mathrm{L}^{-1}$ in rivers are usually associated to eutrophic conditions. This was the case of three out of the four rivers studied with the lowest drainage areas (Iguaçu, Arroio Toledo and Passaúna Rivers, mean total phosphorus concentrations: 1.4, 0.4 and 0.4 mg. $\mathrm{L}^{-1}$, and drainage areas: 814,61 and $27 \mathrm{~km}^{2}$, respectively). This is probably related to inputs of untreated (or only partially treated) wastewaters. In the case of the Iguaçu River, which had the greatest concentration, its watershed had the highest percentage of urban areas in comparison to the others (Table 1, $92 \%)$. On the other hand, total phosphorus concentrations were frequently lower in rivers with larger drainage areas, with averages always below 0.09 mg.L ${ }^{-1}$.

The availability of phosphorus as a result of anthropogenic activities is common at least during part of the river regime. This occurs not only in Brazil, but also in watersheds in other countries and may be due to the impacts of urbanization. For example, a recent study (WILK; ORLIŃSKA-WOŹNIAK; GĘBALA, 2018) was carried out in Polish rivers using SWAT (Soil and Water Assessment Tool) to assess their self-purification capacity. Although the authors found positive retention values (i.e., the actual simulated phosphorus load was lower than that allowed by legislation) for most water bodies, they highlighted the negative impact of urbanization. River sections downstream from the city of Poznan, one of the most populous Polish cities, were not able to assimilate phosphorus loads, and the nutrient was exported downstream.

The different sizes of drainage areas and the contrasting land use types can significantly influence the quantitative and qualitative aspects of water resources. Taffarello et al. (2016) observed significant correlations between nutrient loads and drainage areas in watersheds located in the Cantareira System (São Paulo and Minas Gerais States). The authors concluded that these results can serve as a basis for regionalization studies of pollutant loads and also to predict such loads and the pollution level in general affecting local aquatic systems. Other studies have also indicated that although the analysis of water quality variables in terms of concentration is useful for comparisons with standards and guidelines, determining the loads of pollutants (based on paired quality and discharge data) represents an important contribution towards water resources management (QUILBÉ et al., 2006; SCANLON; KIELY; XIE, 2004).

Six out of the eight rivers studied can be considered inappropriate for primary contact recreation (exceptions were the Piraquara and Arroio Toledo Rivers, PR) based on average values of thermotolerant coliforms. According to the CONAMA 274 (BRASIL, 2001), the upper limit for such a variable is $2.510^{3} \mathrm{CFU} / 100 \mathrm{~mL}$ for safe bathing conditions. Considering water uses other than primary contact recreation, CONAMA 357 (BRASIL, 2005) is even more restrictive. According to this resolution, the limit of $1.010^{3} \mathrm{CFU} / 100 \mathrm{~mL}$ (Class 2) cannot be exceeded in $80 \%$ or more cases of at least six samples collected bimonthly in one year.

The thermotolerant coliforms presented, in general, smaller variation in the rivers with greater drainage areas (means of 5 to $910^{3} \mathrm{CFU} / 100 \mathrm{~mL}$ ) (Table 2). Taffarello et al. (2016) found a variation of thermotolerant coliforms from $14 \mathrm{CFU} / 100 \mathrm{~mL}$ to $1,00010^{3} \mathrm{CFU} / 100 \mathrm{~mL}$ in catchments with drainage areas between 10 and $1,000 \mathrm{~km}^{2}$ in their study. In our research, drainage areas varied between 27 and 26,500 $\mathrm{km}^{2}$ (Table 1), and the coliforms varied from $<110^{3}-3,30010^{3} \mathrm{CFU} / 100 \mathrm{~mL}$. This suggests greater faecal enrichment in the rivers with lower discharges and possibly less capacity of dilution and self-depuration. However, there are uncertainties in the quantification of thermotolerant coliforms 
Table 2. Mean (minimum-maximum) values of observed discharge $\left(\mathrm{Q}, \mathrm{m}^{3} \cdot \mathrm{s}^{-1}\right)$, total phosphorus $\left(\mathrm{TP}\right.$, mg. $\left.\mathrm{L}^{-1}\right)$ and thermotolerant coliforms (TC, $10^{3} \mathrm{CFU} / 100 \mathrm{~mL}$ ) in the studied rivers, as well as important parameters obtained from the frequency curves (see Figures 1-4). The percentage of time $\left(\operatorname{Prob}_{\mathrm{TP}}\right.$ and $\operatorname{Prob}_{\mathrm{TC}}$ ) indicates the duration of the non-compliance between the observed loads and the admissible ones (based on the legal framework) for TP and TC. The respective critical discharges $\left(\mathrm{Q}_{\mathrm{CRIT}}, \mathrm{m}^{3} \cdot \mathrm{s}^{-1}\right)$ and critical loads $\left(\operatorname{Load}_{\text {CRIT }}\right.$, either in t.day ${ }^{-1} \mathrm{~km}^{-2}$ or in $10^{12}$ CFU.day $\left.{ }^{-1} \cdot \mathrm{km}^{-2}\right)$, above which there was no compliance with the environmental standards, are also shown. The rivers were ordered according to their drainage areas in descending order.

\begin{tabular}{|c|c|c|c|c|c|c|c|c|c|}
\hline River & $\begin{array}{c}\mathrm{Q} \\
\left(\mathrm{m}^{3} \cdot \mathrm{s}^{-1}\right)\end{array}$ & $\begin{array}{c}\mathrm{TP} \\
\left(\mathrm{mg} \cdot \mathrm{L}^{-1}\right)\end{array}$ & $\begin{array}{c}\text { TC } \\
\left(10^{3} \mathrm{UFC} / 100 \mathrm{~mL}\right)\end{array}$ & $\begin{array}{c}\text { Prob }_{\text {TP }} \\
(\%)\end{array}$ & 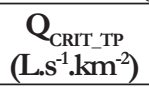 & $\begin{array}{l}\text { Load }_{\text {CRIT_TP }} \\
\left(\text { t.day }^{-1} \cdot \mathrm{km}^{-2}\right)\end{array}$ & $\begin{array}{c}\text { Prob }_{\mathrm{TC}} \\
(\%)\end{array}$ & 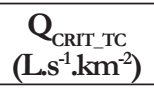 & $\begin{array}{c}\text { Load }_{\text {CRIT_TC }} \\
\left(10^{12} \text { CFU.day }{ }^{-1} \cdot \mathrm{km}^{-2}\right)\end{array}$ \\
\hline $\begin{array}{c}\text { Das Velhas } \\
\text { (MG) }\end{array}$ & $\begin{array}{c}255 \\
(56-1.165)\end{array}$ & $\begin{array}{c}0.07 \\
(0.01-0.34)\end{array}$ & $\begin{array}{c}9 \\
(<1-160)\end{array}$ & 25 & 15 & $>210^{-4}$ & 35 & 10 & $>310^{-2}$ \\
\hline $\begin{array}{l}\text { Doce } \\
(\mathrm{MG})\end{array}$ & $\begin{array}{c}242 \\
(88-893)\end{array}$ & $\begin{array}{c}0.05 \\
(0.01-0.17)\end{array}$ & $\begin{array}{c}6 \\
(<1-160)\end{array}$ & 15 & 28 & $>510^{-4}$ & 35 & 15 & $>310^{-2}$ \\
\hline $\begin{array}{l}\text { Pomba } \\
\text { (MG) }\end{array}$ & $\begin{array}{c}91 \\
(24-245)\end{array}$ & $\begin{array}{c}0.05 \\
(0.01-0.14)\end{array}$ & $\begin{array}{c}5 \\
(<1-35)\end{array}$ & 10 & 37 & $>510^{-4}$ & 75 & 9 & $>110^{-2}$ \\
\hline $\begin{array}{c}\text { Paraopeba } \\
\text { (MG) }\end{array}$ & $\begin{array}{c}39 \\
(1-159)\end{array}$ & $\begin{array}{c}0.09 \\
(0.01-0.46)\end{array}$ & $\begin{array}{c}8 \\
(<1-50)\end{array}$ & 15 & 27 & $>610^{-4}$ & 25 & 21 & $>110^{-1}$ \\
\hline $\begin{array}{l}\text { Iguaçu } \\
\text { (PR) }\end{array}$ & $\begin{array}{c}77 \\
(12-274)\end{array}$ & $\begin{array}{c}1.4 \\
(0.5-3.7)\end{array}$ & $\begin{array}{c}3.300 \\
(1-9.999)\end{array}$ & 100 & $<20$ & $>810^{-3}$ & 100 & $<20$ & $>510^{-2}$ \\
\hline $\begin{array}{l}\text { Piraquara } \\
(\mathrm{PR})\end{array}$ & $\begin{array}{c}7 \\
(2-32)\end{array}$ & $\begin{array}{c}0.04 \\
(0.02-0.08)\end{array}$ & $\begin{array}{c}<1 \\
(<1-<1)\end{array}$ & 5 & 150 & $>110^{-3}$ & 55 & 26 & $>110^{-1}$ \\
\hline $\begin{array}{l}\text { A. Toledo } \\
\text { (PR) }\end{array}$ & $\begin{array}{c}2 \\
(1-7)\end{array}$ & $\begin{array}{c}0.4 \\
(0.13-0.88)\end{array}$ & $\begin{array}{c}<1 \\
(<1-2)\end{array}$ & 100 & $<20$ & $>310^{-3}$ & 25 & 26 & $>110^{-1}$ \\
\hline $\begin{array}{l}\text { Passaúna } \\
\text { (PR) }\end{array}$ & $\begin{array}{c}<1 \\
(<1-1)\end{array}$ & $\begin{array}{c}0.4 \\
(0.1-0.9)\end{array}$ & $\begin{array}{c}22 \\
(<1-130)\end{array}$ & 100 & $<13$ & $>110^{-4}$ & 85 & 10 & $>110^{-2}$ \\
\hline
\end{tabular}

MG = Minas Gerais State; PR = Paraná State.

due to both their metabolic versatility that changes their growth rates and possible limitations in laboratory counting methods.

Urbanization and soil sealing were associated with increased concentrations of phosphorus and coliforms in North American (SCHOONOVER; LOCKABY, 2006) and European rivers (WILK; ORLIŃSKA-WOŹNIAK; GĘBALA, 2018). The transport of pollutant loads to rivers can significantly vary within the same type of land use, depending on factors such as slope and soil characteristics (IMANI et al., 2017; GHEBREMICHAEL; VEITH; WATZIN, 2010). In addition to unplanned land use, the inputs of domestic wastewater can also cause a river discontinuity and alter the physical, chemical and biological characteristics of the river downstream from the release (SEANEGO; MOYO, 2013). In the water bodies we studied, there are anthropogenic impacts with different typologies and magnitudes. Untreated effluent (point sources) and surface runoff (non-point sources) are certainly associated with the relatively high concentrations of total phosphorus and thermotolerant coliforms in some cases.

\section{Integrating frequency curves on water quantity and water quality}

The frequency curves estimated the percentage of time during which there was no compliance of observed specific loads with those admissible based on Brazilian environmental standards and legal framework for each variable. Moreover, such an approach facilitated the visualization of the most critical hydrological regime in terms of no compliance of pollutant loads with environmental standards.

The interpretation of the 'Prob' and ' $\mathrm{Q}_{\mathrm{CRIT}}$ ' parameters shown in Table 2 is as follows. For example, for Das Velhas River, with a predominantly agricultural land use and drainage area of $26,500 \mathrm{~km}^{2}$, there are two pairs of critical values ('Prob', ' $\mathrm{Q}_{\mathrm{CRIT}}{ }^{\prime}$ ): $\left(25 \%, 15 \mathrm{~L} \cdot \mathrm{s}^{-1} \cdot \mathrm{km}^{-2}\right)$ for total phosphorus and $\left(35 \%, 10 \mathrm{~L} \cdot \mathrm{s}^{-1} \cdot \mathrm{km}^{-2}\right)$ for thermotolerant coliforms. In summary, Das Velhas River had no compliance during 25 to $35 \%$ of the duration of the annual regime for total phosphorus and coliforms, considering a range of critical specific discharges between 10 and $15 \mathrm{~L} \cdot \mathrm{s}^{-1} \cdot \mathrm{km}^{-2}$. Another example is the Piraquara River, which is located in a predominantly urbanized watershed with a drainage area of $102 \mathrm{~km}^{2}$. For this river, non-compliance with the legal framework varied between 5 and $55 \%$ of the time, with critical specific discharges ranging from 26 to $150 \mathrm{~L} \cdot \mathrm{s}^{-1} \cdot \mathrm{km}^{-2}$.

Such time intervals and critical discharges can contribute to a more flexible approach regarding the legal framework of the Brazilian water bodies. This framework is currently solely based on single values of concentrations and reference discharges, according to Art. 10 and 38 from CONAMA 357/2005 (BRASIL, 2005). On the other hand, these intervals also bring challenges when proposing the most suitable 'ecological flows' for a given watershed. The durations or frequencies described above represent a fraction of duration in one year (or typical regime with annual basis); in our study, differences in data availability were not considered prohibitive to compare results throughout the studied watersheds.

For some watersheds, non-compliance with the legal framework reached $100 \%$ of the time in relation to total phosphorus and coliforms' loads (Table 2). Considering both variables, the Doce and Paraopeba Rivers presented the best conditions (Figures 1-4). On the other hand, the Passaúna and Iguaçu Rivers had a more critical situation (an inadequate condition for both variables during at least $85 \%$ of the time). 
Phosphorus and thermotolerant coliforms' load in Brazilian watersheds with limited data: considerations on the integrated analysis of water quality and quantity

The observed specific loads for total phosphorus (Figures 1-2) presented conflicts with the loads in compliance with the legal framework especially for the rivers with smaller drainage areas
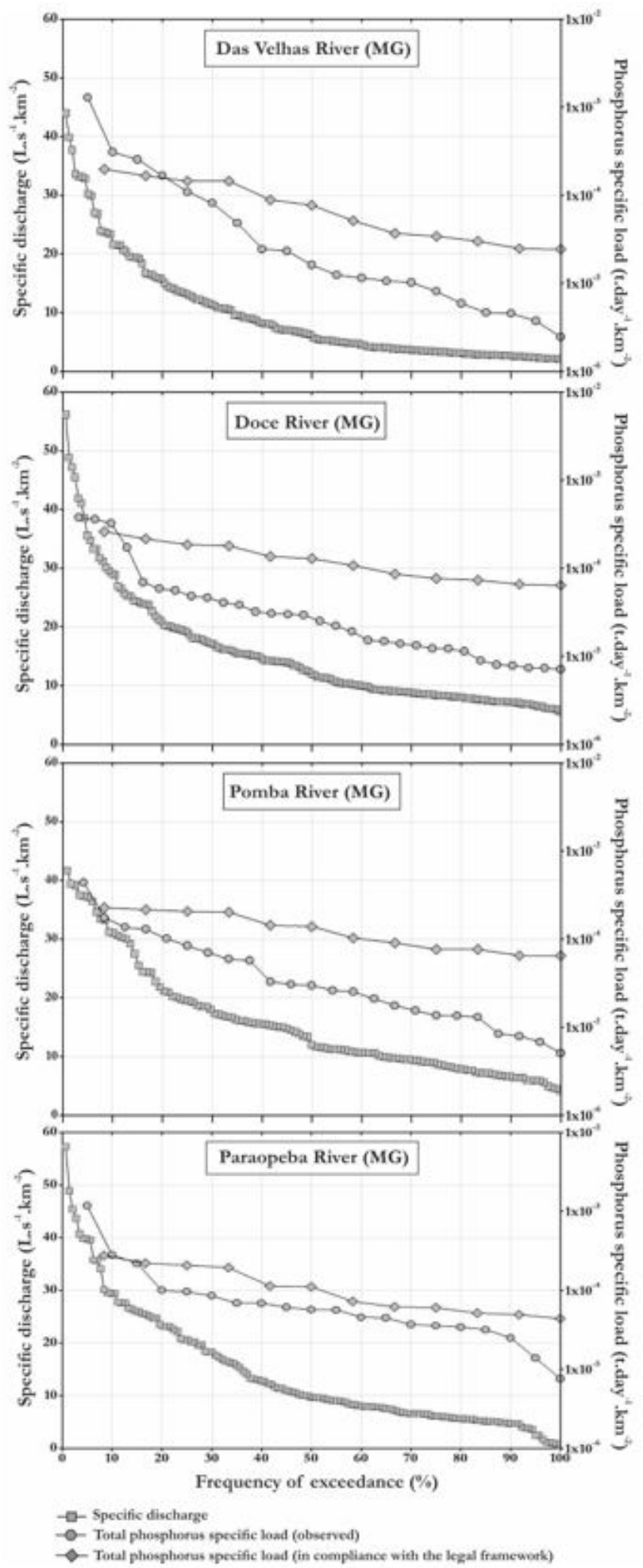

Figure 1. Frequency curves for specific discharge $\left(\mathrm{L}_{\mathrm{s}} \mathrm{s}^{-1} \cdot \mathrm{km}^{-2}\right)$ and total phosphorus specific loads ("observed loads" and "loads in compliance with the legal framework") $\left(10^{12}\right.$ CFU.day $\left.{ }^{-1} \cdot \mathrm{km}^{-2}\right)$ for Das Velhas, Doce, Pomba, and Paraopeba Rivers (refer to Tables 1 and 2).
$(100 \%$ in the case of the Iguaçu, Arroio Toledo and Passaúna Rivers). In these rivers, the critical loads of phosphorus were $810^{-3}, 310^{-3}$ and $110^{-4}$ t.day ${ }^{-1} \cdot \mathrm{km}^{-2}$, respectively, and associated
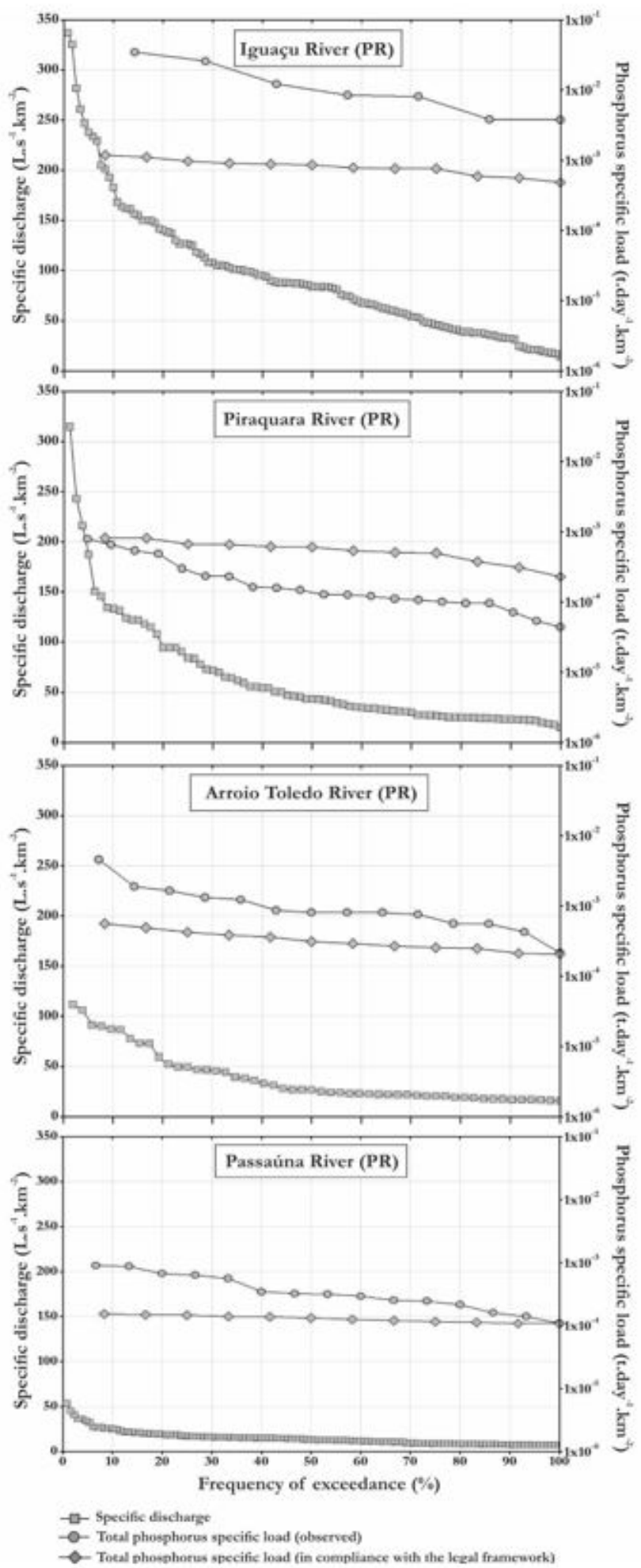

Figure 2. Frequency curves for specific discharge $\left(\mathrm{L}_{\mathrm{s}}{ }^{-1} \cdot \mathrm{km}^{-2}\right)$ and total phosphorus specific loads ("observed loads" and "loads in compliance with the legal framework") $\left(10^{12}\right.$ CFU.day $\left.{ }^{-1} \cdot \mathrm{km}^{-2}\right)$ for Iguaçu, Piraquara, Arroio Toledo, and Passaúna Rivers (refer to Tables 1 and 2). 
with critical discharges of 20, 20 and 13 L.s. ${ }^{-1} \cdot \mathrm{km}^{-2}$ (Table 2). Increasing anthropogenic pressures on the Passaúna River (PR) were reported by Xavier (2005), with the main degradation drivers
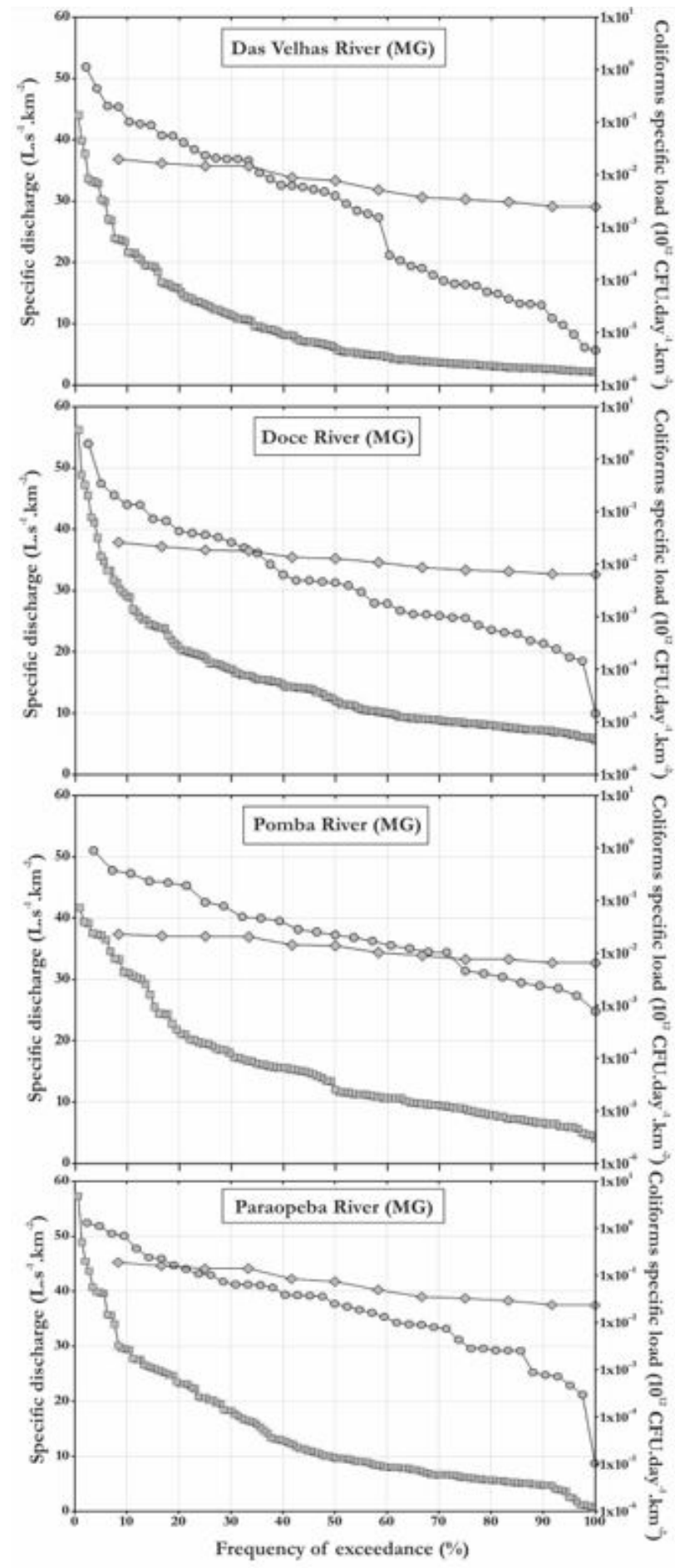

-1) Specific discharge

- - Thermotolerant colifoems specific load (observed)

- Thermotoletant coliforms specific load (in compliance with the legal framewonk)

Figure 3. Frequency curves for specific discharge $\left(\mathrm{L} \cdot \mathrm{s}^{-1} \cdot \mathrm{km}^{-2}\right)$ and thermotolerant coliforms specific loads ("observed loads" and "loads in compliance with the legal framework") $\left(10^{12}\right.$ CFU.day $\left.{ }^{-1} \cdot \mathrm{km}^{-2}\right)$ for Das Velhas, Doce, Pomba, and Paraopeba Rivers (refer to Tables 1 and 2). related to unplanned urban sprawl and agricultural development even for the canopy areas. The frequency curves for this river (Figure 2) reinforced the critical situation of exceedance of total
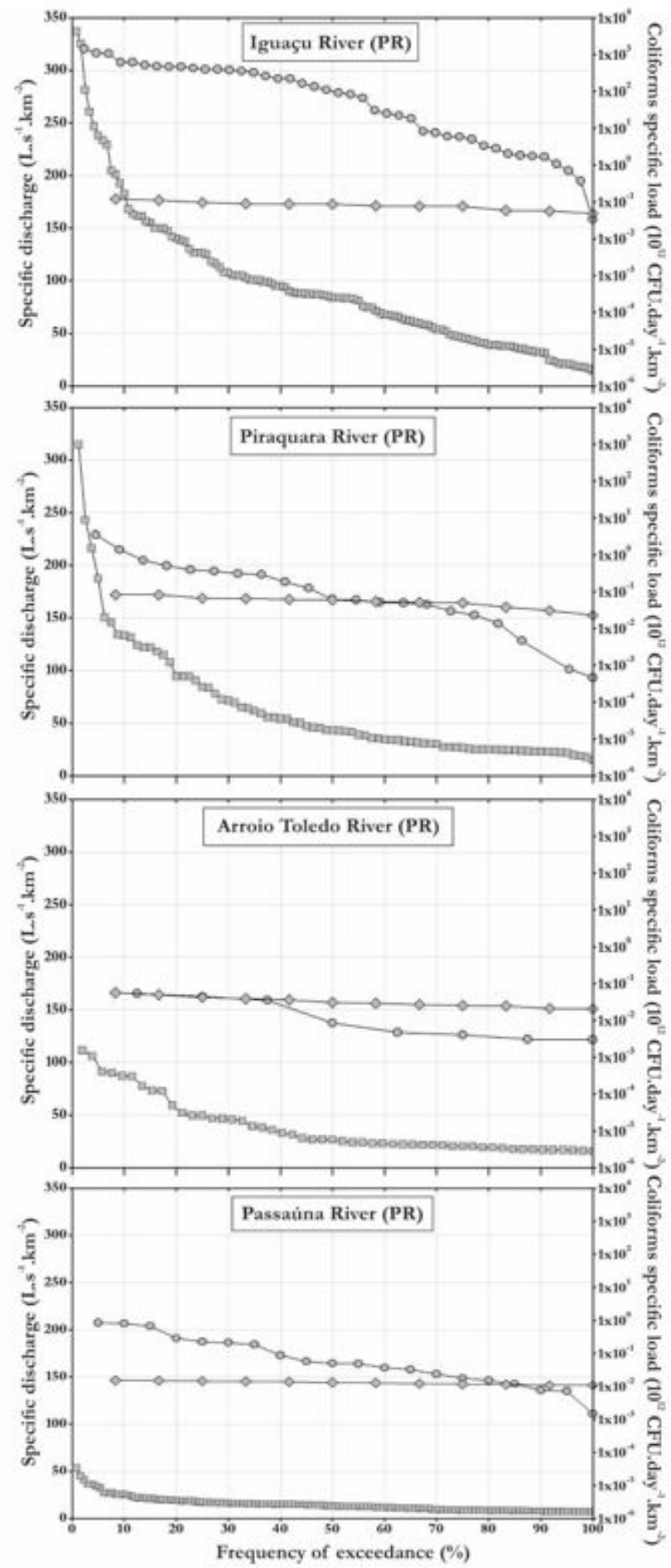

$-9-$ Specific discharge

- Thermotoletant coliforms specific load (observed)

- Mnermotolerant coliforms specifie load (in compliance with the kegal framework)

Figure 4. Frequency curves for specific discharge $\left(\mathrm{L}_{\mathrm{s}}{ }^{-1} \cdot \mathrm{km}^{-2}\right)$ and thermotolerant coliforms specific loads ("observed loads" and "loads in compliance with the legal framework") $\left(10^{12}\right.$ CFU.day $\left.{ }^{-1} \cdot \mathrm{km}^{-2}\right)$ for Iguaçu, Piraquara, Arroio Toledo, and Passaúna Rivers (refer to Tables 1 and 2). 
Phosphorus and thermotolerant coliforms' load in Brazilian watersheds with limited data: considerations on the integrated analysis of water quality and quantity

phosphorus, both in terms of concentration (Table 2) and specific loads. These results highlight the significant organic matter sources in the Passaúna River watershed.

A similar situation was observed for the Iguaçu River (Figure 2), for which the non-compliance in 100\% of the time is consistent with recent studies reporting the increasing pollution levels in this aquatic system (KNAPIK et al., 2011; JACOBS, 2002). One of the main drinking water supply sources in the Metropolitan Region of Curitiba therefore requires the design of restoration actions and environmental recovery plans (CENGIZ, 2013). In this context, planning and monitoring approaches adopted in other watersheds that could be adapted considering the regional characteristics of the Iguaçu River watershed can be found in Silva (2017).

The specific loads of thermotolerant coliforms significantly varied in the rivers (Figures 3 and 4). The most critical situations were verified, as for total phosphorus, in the rivers with smaller drainage areas, in this case the Piraquara, Passaúna and Iguaçu Rivers. For these water bodies, the observed loads exceeded the admissible loads in $55 \%, 85 \%$ and $100 \%$ of the time, respectively (Table 2, Figure 4). The less critical situation for the coliforms was observed in the Paraopeba and Arroio Toledo Rivers (no compliance in $25 \%$ of the time), associated to critical discharges of 21 and $26 \mathrm{~L} \cdot \mathrm{s}^{-1} \cdot \mathrm{km}^{-2}$, respectively (Table 2, Figure 3). For thermotolerant coliforms in the studied rivers, critical loads with an order of magnitude between $10^{10}-10^{11}$ CFU.day ${ }^{-1} \cdot \mathrm{km}^{-2}$ were already able to generate no compliance with loads compatible with the environmental standards.

Some rivers (Table 2) presented favorable situations for one variable and unfavorable for the other. Various researchers (e.g., LYON et al., 2012; KIRCHNER, 2009; OUYANG et al., 2006) highlighted the significant environmental variability of watersheds in both temporal and spatial scales. Besides the seasonal variation, which was not directly addressed in the present study, water bodies are submitted to multiple stressors, such as agricultural activities and urban sprawl, contributing to a significant variability of water quality. These stressors can act in an additive way or not and generate significant changes in the physical and chemical characteristics of water, as well as in the biological communities and ecosystem processes (TANIWAKI et al., 2017). In the case of the eight rivers we analyzed, additional investigations are required for the causes that have led, in most cases, to water quality issues in relation to total phosphorus and coliforms. The fact that the watersheds had limited datasets available also reinforces uncertainties.

For the Pomba River, the total phosphorus specific load (observed) remained compatible with the legal framework, but the opposite occurred with the thermotolerant coliforms specific load. Guedes et al. (2011) studied the Pomba River and related the variations in its water quality to non-point pollution from fertilizers, as well as to the inputs of solids, nutrients and organic matter from untreated wastewater. However, according to the results of the present study, the total phosphorus specific loads in this water body were below those compatible with CONAMA 357/2005 most of the time $(90 \%)$. The thermotolerant coliforms specific loads in turn were above the limit in $75 \%$ of the time (Figure 3 ).

For the Arroio Toledo River (drainage area: $61 \mathrm{~km}^{2}$ ), phosphorus and thermotolerant coliforms' specific loads were not compatible and compatible with the admissible loads, respectively. Concerning the high phosphorus loads observed, they can be associated to the use of fertilizers, since the Arroio Toledo watershed is mainly ( $89 \%$ ) agricultural, leading to losses and transport of phosphorus from agricultural soils to surface waters, as observed by other researchers (FISCHER et al., 2017; SATTARI et al., 2012). The Arroio Toledo River presented a favorable situation regarding the observed loads of thermotolerant coliforms most of the time. For this variable, the Iguaçu River presented the most critical situation (non-compliance with the environmental standards in 100\% of the time). However, although thermotolerant coliforms are associated with impacts of human activities on water quality (NIEWEGLOWSKI, 2006), they do not necessarily indicate faecal contamination. Therefore, the adoption of more accurate indicators, such as Escherichia coli, may contribute to the more effective monitoring of the water bodies (HACHICH et al., 2012). In this case, the frequency curves would be even more representative from the point of view of fecal contribution if they considered Escherichia coli.

Considering this discussion, it should be noted that there is a great variability of criteria for adopting reference flows and defining water use licensing across different Brazilian states. The reference discharge considered by decision-makers to establish the water use license is not always appropriate for rivers under significant seasonal variations or submitted to extreme hydrological events. As an alternative to improve policies on water resources management, in our paper, we used the mean monthly discharges of the rivers to estimate the pollutants' loads. However, other reference discharges/metrics can be tested - e.g., $\mathrm{Q}_{95}$, or long term median discharge - depending on the interests or goals of the research. (Re)constructing the frequency curves for the studied rivers using discharges calculated through other statistical parameters $\left(\mathrm{Q}_{95}, \mathrm{Q}_{\text {median }}\right.$ etc.) to promote the water quali-quantitative integration might allow the visualization of the hydrological regime of the rivers, as well as their critical loads over time.

The potential advantages of the qualitative-quantitative integration addressed in this study are still limited by the current Brazilian legal framework. Current national legislation on water use licensing and water bodies framework generally consider constant/fixed reference flows, neglecting the temporal variability of the hydrological regime (PINTO; RIBEIRO; SILVA, 2016). This also raises questions about the effectiveness of the ecological flows for maintaining the aquatic biota and the functioning of the ecosystems (VESTENA et al., 2012), for which the variations on hydrological fluxes are determinant (TIMPE; KAPLAN, 2017). For example, in Minas Gerais State, the IGAM (Instituto Mineiro de Gestão de Águas) (Law 13, 199/1999) authorizes the use and licensing of up to $50 \%$ of $Q_{7,10}$ of state water bodies. This value can be lower (e.g., $30 \%$ of $\mathrm{Q}_{710}$ ) in specific watersheds, including Paraopeba and Das Velhas. On the other hand, in Paraná State, the IAP (Instituto das Águas do Paraná) (Law 12,726/1999) defines $50 \%$ of $\mathrm{Q}_{95}$ as maximum water withdrawal in local rivers and streams.

A complementary approach to the qualitative-quantitative integration presented in our paper may be the Hydrological Services Index (HSI) developed by Taffarello et al. (2018). HSI is a composite index, determined from qualitative-quantitative frequency curves 
that incorporate the gray water footprint (HOEKSTRA et al., 2011), i.e. the water volume required for pollution abatement and dilution. The index evaluates water pollution from phosphate, nitrate and sediments in an integrated way. The HSI can be useful to compare the level of pollution across different watersheds based on a reference catchment. Similarly, Tucci (2017) proposed a Water Sustainability Indicator that can be widely used in urban areas.

Another significant contribution to effective water resources management, considering that limited data is still a challenge, may be the participatory monitoring of water resources, as described by Carolino and Pereira (2014). Additionally, Khan et al. (2017) emphasized that sustainable water resources management should encompass not only the ways people benefit from ecosystem services, but also the anthropogenic impacts on natural watersheds, which brings a demand for a quali-quantitative and socio-hydrological approach. The latter seeks the understanding of the hydrological cycle modified by the human action in both temporal and spatial scales, emphasizing the bidirectional interactions between humans and water systems (MENDIONDO et al., 2017; SIVAPALAN; SAVENIJE; BLÖSCHL, 2012; SIVAPALAN et al., 2014).

\section{CONCLUSIONS}

Frequency curves can efficiently integrate qualitative and quantitative aspects of aquatic systems. Although our study was limited by data availability and sampling uncertainties, these curves can be considered potentially interesting for water resources management. In the rivers studied, considering at least two water quality variables, rivers with different drainage areas and land use at the watershed level presented significant variability of discharges, loads and critical durations (i.e., periods of time during which there was non-compliance of observed specific loads with those admissible based on Brazilian environmental standards and legal framework). Regarding total phosphorus and thermotolerant coliforms, based on average discharge, we observed potential negative influences on water uses and risks to the ecosystem services provided by the studied rivers. For both variables, we observed a high degree of non-compliance with the legal framework over time based on the integration of water quantitative and qualitative datasets.

We expect our results can help regionalization studies, associating critical durations and critical flows that lead to a situation of non-compliance of pollutant loads with environmental standards. However, challenges regarding the use of frequency curves addressed in this study include the significant variability of the hydrological regime, multiple and synergistic human interferences on rivers, as well as the paucity of paired data on water quality and discharge (i.e., there are still limited and/or fragmented databases on Brazilian water bodies). This indicates that a new thinking would be necessary to take advantage of this dynamics in the future and incorporate it into traditional methods of estimating ecological flows, which are still quite dependent on almost exclusively quantitative approaches.

We suggest that future studies seek to identify the main causes of non-compliances in the rivers studied, possibly the inputs of domestic and industrial wastewaters, and the surface runoff from agricultural and urban areas. Mechanisms for control, revitalization and recovery of watersheds can be proposed, especially for those that are used as sources for drinking water supplies. We expect the present study can support integrated water resources management to ensure multiple uses in the long term. We encourage the use of such an integrative approach in future environmental monitoring and evaluation initiatives applied to ecological flows and remaining flows within catchments with limited data and significant uncertainties.

\section{ACKNOWLEDGEMENTS}

The authors are grateful to the São Paulo Research Foundation (FAPESP) for the undergraduate scholarship awarded to L.O.A. Marques (Process 2013/19465-3), the postdoc scholarship granted to D.G.F. Cunha (Process 2012/21254-8), and the PhD scholarship awarded to D. Taffarello (Process 2012/22013-4). The authors would also like to thank the National Council for Scientific and Technological Development (CNPq) for the productivity grants awarded to E.M. Mendiondo (Process 312056/2016-8) and to D.G.F. Cunha (Process 300899/2016-5). Finally, the authors would like to thank the Coordination for the Improvement of Higher Education Personnel (CAPES) for the postdoc scholarship to D. Taffarello (CAPES/PNPD). The authors declare no conflict of interest and possibility of free access to the original datasets for research purposes upon request. Two anonymous reviewers and the handling editor provided insightful comments for improving the manuscript, which were greatly appreciated.

\section{REFERENCES}

ABU-HMEIDAN, H. Y.; WILLIAMS, G. P.; MILLER, A. W. Characterizing total phosphorus in current and geologic Utah Lake sediments: implications for water quality management issues. Hydrology, v. 5, n. 1, p. 8, 2018. http://dx.doi.org/10.3390/ hydrology5010008.

ARTHINGTON, A. H.; BUNN, S. E.; POFF, N. L.; NAIMAN, R. $\mathrm{J}$. The challenge of providing environmental flow rules to sustain river ecosystems. Ecological Applications, v. 16, n. 4, p. 1311-1318, 2006. http://dx.doi.org/10.1890/1051-0761(2006)016[1311:TC OPEF]2.0.CO;2. PMid:16937799.

BRASIL. Conselho Nacional do Meio Ambiente - CONAMA. Resolução no 274 , de 29 de novembro de 2000. Define os critérios de balneabilidade em águas brasileiras. Diário Oficial [da] República Federativa do Brasil, Brasília, DF, 25 jan. 2001.

BRASIL. Conselho Nacional do Meio Ambiente - CONAMA. Resolução n 357, de 17 de março de 2005. Estabelece a classificação das águas doces, salobras e salinas do Território Nacional. Diário Oficial [da] República Federativa do Brasil, Brasília, DF, 18 mar. 2005.

BROWN, A. E.; WESTERN, A. W.; MCMAHON, T. A.; ZHANG, L. Impact of forest cover changes on annual streamflow and flow duration curves. Journal of Hydrology, v. 483, p. 39-50, 2013. http:/ / dx.doi.org/10.1016/j.jhydrol.2012.12.031. 
Phosphorus and thermotolerant coliforms' load in Brazilian watersheds with limited data: considerations on the integrated analysis of water quality and quantity

BU, H.; MENG, W.; ZHANG, Y.; WAN, J. Relationships between land use patterns and water quality in the Taizi River basin, China. Ecological Indicators, v. 41, p. 187-197, 2014. http://dx.doi. org/10.1016/j.ecolind.2014.02.003.

CALMON, A. P. S.; SOUZA, J. C.; REIS, J. A. T.; MENDONÇA, A. S. F. Uso combinado de curvas de permanência de qualidade e modelagem da autodepuração como ferramenta para suporte ao processo de enquadramento de cursos d'água superficiais. Revista Brasileira de Recursos Hídricos, v. 21, n. 1, p. 118-133, 2016. http:/ / dx.doi.org/10.21168/rbrh.v21n1.p118-133.

CAROLINO, D. M.; PEREIRA, N. C. Análise do ambiente no entorno da escola com ênfase no estudo da água. In: ICLOC: PRÁTICAS NA SALA DE AULA, 6., 2014, São Paulo. Anais... São Paulo: Instituto Cultural Lourenço Castanho, 2014.

CENGIZ, B. Urban river landscapes. In: ÖZYAVUZ, M. (Ed.). Advances in landscape architecture. London: InTech, 2013. 938 p. Available from: <https://www.intechopen.com/books/advancesin-landscape-architecture/urban-river-landscapes>. Access on: 11 july 2017.

CHEN, C. F.; TSAI, L. Y.; FAN, C. H.; LIN, J. Y. Using exceedance probability to determine total maximum daily loads for reservoir water quality management. Water, v. 8, n. 11, p. 541, 2016. http:// dx.doi.org/10.3390/w8110541.

CHUNG, E. S.; KIM, K. T.; LEE, K. S.; BURIAN, S. J. Incorporating uncertainty and objective load reduction allocation into the total maximum daily load process in Korea. KSCE Journal of Civil Engineering, v. 15, n. 7, p. 1289-1297, 2011. http://dx.doi. org/10.1007/s12205-011-1166-0.

COLLISCHONN, W.; DORNELLES, F. Hidrologia para engenharia e ciências ambientais. Porto Alegre: Associação Brasileira de Recursos Hídricos, 2013.

COMPANHIA AMBIENTAL DO ESTADO DE SÃO PAULO - CETESB. Qualidade das águas interiores no Estado de São Paulo: significado ambiental e sanitário das varáveis de qualidade das águas e dos sedimentos e metodologias analíticas e de amostragem. São Paulo: CETESB, 2009.

\section{CONVENTION ON BIOLOGICAL DIVERSITY - CBD.}

$X / 33$ : biodiversity and climate change: decision adopted by the Conference of the Parties to the Convention on Biological Diversity at its Tenth Meeting. Nagoya: Secretariat of Convention on Biological Diversity, 2010.

COSTANZA, R.; GROOT, R.; SUTTON, P.; VAN DER PLOEG, S.; ANDERSON, S. J.; KUBISZEWSKI, I.; FARBER, S.; TURNER, R. K. Changes in the global value of ecosystem services. Global Environmental Change, v. 26, p. 152-158, 2014. http://dx.doi. org/10.1016/j.gloenvcha.2014.04.002.
CRUZ, J. C.; SILVEIRA, G. D. Disponibilidade hídrica para outorga (i): avaliação por seção hidrológica de referência. Revista Rega: Gestão de Água da América Latina, v. 4, n. 2, p. 51-64, 2007.

CRUZ, J. C.; TUCCI, C. E. M. Estimativa da disponibilidade hídrica através da curva de permanência. Revista Brasileira de Recursos Hidricos, v. 13, n. 1, p. 111-124, 2008. http://dx.doi.org/10.21168/ rbrh.v13n1.p111-124.

CUNHA, D. G. F.; CALIJURI, M. C.; MENDIONDO, E. M. Integração entre curvas de permanência de quantidade e qualidade da água como uma ferramenta para a gestão eficiente dos recursos hídricos. Engenharia Sanitaria e Ambiental, v. 17, n. 4, p. 369-376, 2012. http://dx.doi.org/10.1590/S1413-41522012000400003.

CUNHA, D. G. F.; DODDS, W. K.; CALIJURI, M. C. Defining nutrient and biochemical oxygen demand baselines for tropical rivers and streams in São Paulo State (Brazil): A comparison between reference and impacted sites. Environmental Management, v. 48, n. 5, p. 945-956, 2011. http://dx.doi.org/10.1007/s00267011-9739-8. PMid:21858554.

FERREIRA, D. M.; FERNANDES, C. V. S.; KAVISKI, E. Curvas de permanência de qualidade da água como subsídio para o enquadramento de corpos d'água a partir de modelagem matemática em regime não permanente. Revista Brasileira de Recursos Hídricos, v. 21, n. 3, p. 479-492, 2016. http://dx.doi.org/10.1590/23180331.011615143 .

FISCHER, P.; PÖTHIG, R.; GÜCKER, B.; VENOHR, M. Phosphorus saturation and superficial fertilizer application as key parameters to assess the risk of diffuse phosphorus losses from agricultural soils in Brazil. The Science of the Total Environment, v. 630, p. 15151527, 2018. http://dx.doi.org/10.1016/j.scitotenv.2018.02.070. PMid:29554769.

FISCHER, P.; PÖTHIG, R.; VENOHR, M. The degree of phosphorus saturation of agricultural soils in Germany: Current and future risk of diffuse P loss and implications for soil P management in Europe. The Science of the Total Environment, v. 599-600, p. 11301139, 2017. http://dx.doi.org/10.1016/j.scitotenv.2017.03.143. PMid:28511358.

FISHER, B.; TURNER, R. K.; MORLING, P. Defining and classifying ecosystem services for decision making. Ecological Economics, v. 68, n. 3, p. 643-653, 2009. http://dx.doi.org/10.1016/j. ecolecon.2008.09.014.

FONSECA, B. M.; MENDONÇA-GALVÃO, L.; PADOVESIFONSECA, C.; ABREU, L. M.; FERNANDES, A. C. M. Nutrient baselines of Cerrado low-order streams: comparing natural and impacted sites in Central Brazil. Environmental Monitoring and Assessment, v. 186, n. 1, p. 19-33, 2014. http://dx.doi.org/10.1007/ s10661-013-3351-8. PMid:23887888.

FREIRE, A. P.; CASTRO, E. C. Análise da correlação do uso e ocupação do solo e da qualidade da água. Revista Brasileira de Recursos 
Hidricos, v. 19, n. 1, p. 41-49, 2014. http://dx.doi.org/10.21168/ rbrh.v19n1.p41-49.

GENZ, F.; LUZ, L. D. Distinguishing the effects of climate on discharge in a tropical river highly impacted by large dams. Hydrological Sciences Journal, v. 57, n. 5, p. 1020-1034, 2012. http:/ / dx.doi.org/10.1080/02626667.2012.690880.

GHEBREMICHAEL, L. T.; VEITH, T. L.; WATZIN, M. C. Determination of critical source areas for phosphorus loss: Lake Champlain basin, Vermont. Transactions of the ASABE, v. 53, n. 5, p. 1595-1604, 2010. http://dx.doi.org/10.13031/2013.34898.

GONZALO, C.; CAMARGO, J. A. The impact of an industrial effluent on the water quality, submersed macrophytes and benthic macroinvertebrates in a dammed river of Central Spain. Chemosphere, v. 93, n. 6, p. 1117-1124, 2013. http://dx.doi.org/10.1016/j. chemosphere.2013.06.032. PMid:23830885.

GOOGLE EARTH. 2018. Available from: < https:/ /www.google. com.br/earth/>. Access on: 11 june 2018.

GROOT, R. S.; WILSON, M. A.; BOUMANS, R. M. J. A typology for the classification, description and valuation of ecosystem functions, goods and services. Ecological Economics, v. 41, n. 3, p. 393-408, 2002. http://dx.doi.org/10.1016/S0921-8009(02)00089-7.

GUEDES, H. A. S.; SILVA, D. D.; RIBEIRO, C. B. M.; MATOS, A. T.; ELESBON, A. A. A.; SILVA, B. M. B.; GOMES, C. R.; LISBOA, L.; MARTINS, V. S. Avaliação da qualidade da água do médio rio Pomba (MG) utilizando análise de agrupamento. In: SIMPÓSIO BRASILEIRO DE RECURSOS HÍDRICOS, 19., 2011, Maceió. Anais... Porto Alegre: ABRH, 2011.

GUPTA, A. D. Implication of environmental flows in river basin management. Physics and Chemistry of the Earth, v. 33, n. 5, p. 298303, 2008. http://dx.doi.org/10.1016/j.pce.2008.02.004.

HACHICH, E. M.; DI BARI, M.; CHRIST, A. P. G.; LAMPARELLI, C. C.; RAMOS, S. S.; SATO, M. I. Z. Comparison of thermotolerant coliforms and Escherichia coli densities in freshwater bodies. Brazilian Journal of Microbiology, v. 43, n. 2, p. 675-681, 2012. http:/ / dx.doi.org/10.1590/S1517-83822012000200032. PMid:24031879.

HOEKSTRA, A. Y.; CHAPAGAIN, A. K.; ALDAYA, M. M.; MEKONNEN, M. M. Water footprint assessment manual. London: Earthscan, 2011.

HSU, T. H.; LIN, J. Y.; LEE, T. C.; ZHANG, H. X.; YU, S. L. A storm event-based approach to TMDL development. Environmental Monitoring and Assessment, v. 163, n. 1-4, p. 81-94, 2010. http:// dx.doi.org/10.1007/s10661-009-0818-8. PMid:19266300.

IMANI, S.; NIKSOKHAN, M. H.; JAMSHIDI, S.; ABBASPOUR, K. C. Discharge permit market and farm management nexus: an approach for eutrophication control in small basins with lowincome farmers. Environmental Monitoring and Assessment, v. 189, n.
7, p. 346, 2017. http://dx.doi.org/10.1007/s10661-017-6066-4. PMid:28634869.

INSTITUTO MINEIRO DE GESTÃO DAS ÁGUAS - IGAM. Boletim anual de qualidade das águas. Belo Horizonte: IGAM, 2013.

JACOBS, G. A. Dinâmica de uso e ocupação dos mananciais na Região Metropolitana de Curitiba - PR. 2002. 255 f. Tese (Doutorado em Engenharia Florestal) - Universidade Federal do Paraná, Curitiba, 2002.

KHAN, H. F.; YANG, Y. C. E.; XIE, H.; RINGLER, C. A Coupled modeling framework for sustainable watershed management in transboundary river basins. Hydrology and Earth System Sciences Discussions, 2017. http://dx.doi.org/10.5194/hess-2017-480.

KIRCHNER, J. W. Catchments as simple dynamical systems: catchment characterization, rainfall-runoff modeling, and doing hydrology backward. Water Resources Research, v. 45, n. 2, p. W02429, 2009. http://dx.doi.org/10.1029/2008WR006912.

KNAPIK, H.; FERNANDES, C.; PICKBRENNER, K.; PORTO, M.; BASSANESI, K. Qualidade da água da Bacia do Rio Iguaçu: diferenças conceituais entre os modelos QUAL2E e QUAL2K. Revista Brasileira de Recursos Hidricos, v. 16, n. 2, p. 75-88, 2011. http://dx.doi.org/10.21168/rbrh.v16n2.p75-88.

LAMPARELLI, M. C. Graus de trofia em corpos d'água do estado de São Paulo: avaliação dos métodos de monitoramento. 2004. 238 f. Tese (Doutorado em Ciências) - Universidade de São Paulo, São Paulo, 2004.

LIU, Y.; ENGEL, B. A.; FLANAGAN, D. C.; GITAU, M. W.; MCMILLAN, S. K.; CHAUBEY, I. A review on effectiveness of best management practices in improving hydrology and water quality: needs and opportunities. The Science of the Total Environment, v. 601-602, p. 580-593, 2017. http://dx.doi.org/10.1016/j. scitotenv.2017.05.212. PMid:28575835.

LYON, S. W.; NATHANSON, M.; SPANS, A.; GRABS, T.; LAUDON, H.; TEMNERUD, J.; BISHOP, K. H.; SEIBERT, J. Specific discharge variability in a boreal landscape. Water Resources Research, v. 48, n. 8, p. W08506, 2012. http://dx.doi. org/10.1029/2011WR011073.

MENDIONDO, E. M. Challenging issues of urban biodiversity related to ecohydrology. Brazilian Journal of Biology $=$ Revista Brasileira de Biologia, v. 68, n. 4, p. 983-1002, 2008. Supplement. http:// dx.doi.org/10.1590/S1519-69842008000500007. PMid:19197470.

MENDIONDO, E. M.; TAFFARELLO, D.; ROSA, A.; FAVA, M. C.; ABE, N.; MACEDO, M. B.; LAGO, C. A.; RESTREPO, C. E.; ARIAS, D. A. G.; MOHOR, G. S. Applied sociohydrology using volunteer geographic information (VGI) to integrate ecosystembased adaptation (EbA) and disaster risk reduction (DRR). In: 2017 EUROPEAN GEOPHYSICAL UNION GENERAL ASSEMBLY, 19., 2017, Vienna. Proceedings... Vienna: Copernicus, 2017. p. 18191. 
Phosphorus and thermotolerant coliforms' load in Brazilian watersheds with limited data: considerations on the integrated analysis of water quality and quantity

NIEWEGLOWSKI, A. M. A. Indicadores de qualidade da água na bacia bidrográfica do Rio Toledo - PR. 2006. 218 f. Dissertação (Mestrado em Agronomia) - Universidade Federal do Paraná, Curitiba, 2006.

NUNES, M. L. S.; TAKAHASHI, L. Y.; FERRETI, A. R.; KRIECK, C. A. Projeto Oásis São Paulo e Apucarana. In: PAGIOLA, S.; VON GLEHN, H. C.; TAFFARELLO, D. Experiências de pagamentos por serviços ambientais no Brasil. São Paulo: Secretaria de Estado do Meio Ambiente/Banco Mundial, 2013. p. 49-65.

OUYANG, Y.; NKEDI-KIZZA, P.; WU, Q. T.; SHINDE, D.; HUANG, C. H. Assessment of seasonal variations in surface water quality. Water Research, v. 40, n. 20, p. 3800-3810, 2006. http://dx.doi.org/10.1016/j.watres.2006.08.030. PMid:17069873.

PARUCH, A. M.; MÆHLUM, T. Specific features of Escherichia coli that distinguish it from coliform and thermotolerant coliform bacteria and define it as the most accurate indicator of fecal contamination in the environment. Ecological Indicators, v. 23, p. 140-142, 2012. http://dx.doi.org/10.1016/j.ecolind.2012.03.026.

PINTO, V. G.; RIBEIRO, C. B. M.; SILVA, D. D. Vazão ecológica e arcabouço legal brasileiro. Revista Brasileira de Geografia Física, v. 9, n. 1, p. 91-109, 2016. http://dx.doi.org/10.5935/1984-2295.20160006.

QI, J.; LI, S.; BOURQUE, C. P. A.; XING, Z.; MENG, F. R. Developing a decision support tool for assessing land use change and BMPs in ungauged watersheds based on decision rules provided by SWAT simulation. Hydrology and Earth System Sciences Discussions, p. 1-54, 2017. http://dx.doi.org/10.5194/hess-2017-423.

QUILBÉ, R.; ROUSSEAU, A. N.; DUCHEMIN, M.; POULIN, A.; GANGBAZO, G.; VILLENEUVE, J.-P. Selecting a calculation method to estimate sediment and nutrient loads in streams: application to the Beaurivage River (Québec, Canada). Journal of Hydrology, v. 326, n. 1-4, p. 295-310, 2006. http://dx.doi. org/10.1016/j.jhydrol.2005.11.008.

SADEGH, M.; VRUGT, J. A.; GUPTA, H. V.; XU, C. The soil water characteristic as new class of closed-form parametric expressions for the flow duration curve. Journal of Hydrology, v. 535, p. 438-456, 2016. http://dx.doi.org/10.1016/j.jhydrol.2016.01.027.

SATTTARI, S. Z.; BOUWMAN, A. F.; GILLER, K. E.; VAN ITTERSUM, M. K. Residual soil phosphorusas the missing piece in the global phosphorus crisis puzzle. Proceedings of the National Academy of Sciences of the United States of America, v. 109, n. 16, p. 6348-6353, 2012. http://dx.doi.org/10.1073/pnas.1113675109. PMid:22431593.

SCANLON, T. M.; KIELY, G.; XIE, Q. A nested catchment approach for defining the hydrological controls on non-point phosphorus transport. Journal of Hydrology, v. 291, n. 3-4, p. 218231, 2004. http://dx.doi.org/10.1016/j.jhydrol.2003.12.036.

SCHOONOVER, J. E.; LOCKABY, B. G. Land cover impacts on stream nutrients and fecal coliform in the lower Piedmont of
West Georgia. Journal of Hydrology, v. 331, n. 3-4, p. 371-382, 2006. http://dx.doi.org/10.1016/j.jhydrol.2006.05.031.

SEANEGO, K. G.; MOYO, N. A. G. The effect of sewage effluent on the physico-chemical and biological characteristics of the Sand River, Limpopo, South Africa. Physics and Chemistry of the Earth, v. 66, p. 75-82, 2013. http://dx.doi.org/10.1016/j.pce.2013.08.008.

SILVA, J. C. A. Bacias hidrográficas urbaniz̧adas: renaturalização, revitalização e recuperação: um estudo da Bacia do Jaguaré. 2017. 310 f. Tese (Doutorado em Ciências) - Universidade de São Paulo, São Carlos, 2017.

SIVAPALAN, M.; KONAR, M.; SRINIVASAN, V.; CHHATRE, A.; WUTICH, A.; SCOTTT, C. A.; WESCOAT, J. L.; RODRÍGUEZITURBE, I. Socio-hydrology: use-inspired water sustainability science for the Anthropocene. Earth's Future, v. 2, n. 4, p. 225-230, 2014. http://dx.doi.org/10.1002/2013EF000164.

SIVAPALAN, M.; SAVENIJE, H. H. G.; BLÖSCHL, G. Sociohydrology: a new science of people and water. Hydrological Processes, v. 26, n. 8, p. 1270-1276, 2012. http://dx.doi.org/10.1002/hyp.8426.

SOVACOOL, B. K. Using ecosystem valuation to protect rainforest: the case of the Oasis project. Society \& Natural Resources, v. 24, n. 10, p. 1096-1104, 2011. http://dx.doi.org/10.1080/08941921003733864.

TAFFARELlO, D.; CALIJURI, M. C.; VIANI, R. A. G.; MARENGO, J. A.; MENDIONDO, E. M. Hydrological services in the Atlantic Forest, Brazil: an ecosystem-based adaptation using ecohydrological monitoring. Climate Services, v. 2, p. 1-16, 2017. http://dx.doi.org/10.1016/j.cliser.2017.10.005.

TAFFARELLO, D.; MOHOR, G. S.; CALIJURI, M. C.; MENDIONDO, E. M. Field investigations of the 2013-14 drought through quali-quantitative freshwater monitoring at the headwaters of the Cantareira System, Brazil. Water International, v. 41, n. 5, p. 776-800, 2016.

TAFFARELLO, D.; SRINIVASAN, R.; MOHOR, G. S.; GUIMARÃES, J. L. B.; CALIJURI, M. D. C.; MENDIONDO, E. M. Modelling freshwater quality scenarios with ecosystem-based adaptation in the headwaters of the Cantareira System, Brazil. Hydrology and Earth System Sciences, v. 22, n. 9, p. 4699-4723, 2018. http://dx.doi.org/10.5194/hess-22-4699-2018.

TANIWAKI, R. H.; PIGGOT'T, J. J.; FERRAZ, S. F. B.; MATTHAEI, C. D. Climate change and multiple stressors in small tropical streams. Hydrobiologia, v. 793, n. 1, p. 41-53, 2017. http://dx.doi. org/10.1007/s10750-016-2907-3.

TIMPE, K.; KAPLAN, D. The changing hydrology of a dammed Amazon. Science Advances, v. 3, n. 11, p. e1700611, 2017. http:// dx.doi.org/10.1126/sciadv.1700611. PMid:29109972.

TUCCI, C. E. M. Indicador de sustentabilidade hídrica urbana. Revista Gestão de Água da América Latina, v. 14, p. 1-12, 2017. 
U.S. ARMY CORPS OF ENGINEERS - USACE. Public works technical bulletin: guidelines on the U.S. Environmental Protection Agency's total maximum daily load. Washington: USACE, 2006.

VESTENA, L. R.; OLIVEIRA, E. D.; CUNHA, M. C.; THOMAZ, E. L. Vazão ecológica e disponibilidade hídrica na bacia das Pedras, Guarapuava-PR. Revista Ambiente \& Agua, v. 7, n. 3, p. 212-227, 2012. http://dx.doi.org/10.4136/ambi-agua.840.

VIANI, R. A. G.; BRACALE, H. Produtor de água no PCJ: pagamentos por serviços ambientais: lições aprendidas e próximos passos. São Paulo: The Nature Conservancy, 2015. 80 p.

VÖRÖSMARTY, C. J.; MCINTYRE, P. B.; GESSNER, M. O.; DUDGEON, D.; PRUSEVICH, A.; GREEN, P.; GLIDDEN, S.; BUNN, S. E.; SULLIVAN, C. A.; LIERMANN, C. R.; DAVIES, P. M. Global threats to human water security and river biodiversity. Nature, v. 467, n. 7315, p. 555-561, 2010. http://dx.doi.org/10.1038/ nature09440. PMid:20882010.

WILK, P.; ORLIŃSKA-WOŹNIAK, P.; GĘBALA, J. The river absorption capacity determination as a tool to evaluate state of surface water. Hydrology and Earth System Sciences, v. 22, n. 2, p. 1033-1050, 2018. http://dx.doi.org/10.5194/hess-22-1033-2018.

XAVIER, D. F. C. Avaliação da influência do uso e ocupação do solo de caraterísticas geomorfológicas sobre a qualidade das águas de dois reservatórios da região metropolitana de Curitiba-Paraná. 2005. 154 f. Dissertação (Mestrado em Solos) - Universidade Federal do Paraná, Curitiba, 2005.

YOUNG, C. E. F.; BAKKER, L. B. Payments for ecosystem services from watershed protection: a methodological assessment of the Oásis project in Brazil. Natureza \& Conservação, v. 12, n. 1, p. 71-78, 2014. http://dx.doi.org/10.4322/natcon.2014.013.
ZAFFANI, A. G.; CRUZ, N. R.; TAFFARELLO, D.; MENDIONDO, E. M. Uncertainties in the generation of pollutant loads in the context of disaster risk management using brazilian nested catchment experiments under progressive change of land use and land cover. Journal Physical Chemistry \& Biophysics, v. 5, n. 1, p. 2161-0398, 2015.

ZUCCO, E.; PINHEIRO, A.; DESCHAMPS, F. C.; SOARES, P. A. Metodologia para estimativa das concentrações em cursos de água. Revista de Gestão de Água da América Latina, v. 9, n. 1, p. 25-37, 2012.

\section{Authors contributions}

Luis Otávio do Amaral Marques: Conceptualization, data curation, formal analysis, funding acquisition and writing - original draft preparation.

Denise Taffarello: Writing - formal analysis, writing - review and editing, visualization and supervision.

Maria do Carmo Calijuri: Formal analysis, writing - review and editing, visualization and supervision.

Eduardo Mario Mendiondo: Formal analysis, writing - review and editing, visualization and supervision.

Murilo de Souza Ferreira: Formal analysis, writing - review and editing, visualization and supervision.

Davi Gasparini Fernandes Cunha: Conceptualization, data curation, formal analysis, funding acquisition, writing - review and editing and project administration. 